\title{
Is Physical Evidence Still Valid? A Study of Low Cost Carriers in Indonesia
}

\author{
Yasintha Soelasih \\ Atma Jaya Catholic University of Indonesia, Jakarta
}

\begin{abstract}
Physical evidence has been widely accepted as variable that has impact on satisfaction, specifically in airline service. However, this study showed some opposite result for low cost airlines in Indonesia. It revealed that physical evidence has no effect on the passengers' satisfaction but the fares and its service quality to passengers.' This study collected sample of 317 passengers from commercial domestic flights at terminal 1, 2, and 3 at Soekarno Hatta airport in Cengkareng, Indonesia. The variables used in this study were: fares, service quality, physical evidence, passengers' satisfaction levels and repeat buying. Two variables, i.e.: service quality and physical evidence were treated as second order. This study used Structural Equation Modeling (SEM) for verification analysis. The result revealed that there was no effect of physical evidence on the passengers' satisfaction. It also found that repeat buying demonstrated the passengers' satisfaction.
\end{abstract}

\begin{abstract}
Abstrak: Lingkungan fisik telah diterima secara luas sebagai variabel yang memiliki dampak pada kepuasan, khususnya di perusahaan penerbangan. Namun, penelitian ini menunjukkan hasil yang berlawanan untuk penerbangan murah di Indonesia. Ini mengungkapkan bahwa lingkungan fisik tidak mempunyai pengaruh terhadap kepuasan tetapi tarif dan kualitas pelayanan yang mempunyai pengaruh terhadap kepuasan penumpang. Penelitian ini menggunakan sampel sebanyak 317 penumpang penerbangan domestik komersial pada terminal 1, 2, dan 3 di bandara Soekarno Hatta Cengkareng, Indonesia. Variabel yang digunakan dalam penelitian ini adalah: tarif, kualitas pelayanan, lingkungan fisik, tingkat kepuasan penumpang dan penggunaan kembali. Dua variabel, yaitu: kualitas pelayanan dan lingkungan fisik menggunakan dimensi . Penelitian ini menggunakan Structural Equation Modeling (SEM) untuk analisis verifikasi. Hasil penelitian menunjukkan bahwa tidak terjadi pengaruh lingkungan fisik terhadap kepuasan penumpang. Bila terjadi kepuasan penumpang maka akan menimbulkan penggunaan kembali.
\end{abstract}

Keywords: fares; passengers' satisfaction; physical evidence; repeat buying; service quality

JEL classification: M31

* Corresponding author's e-mail: sinthajkt@yahoo.com 


\section{Introduction}

The growth of airlines in Indonesia began after the deregulation of the airline industry in 1999. Since then, the growth of the airlines has led to a high level of competition among them and also competition in terms of the service they provide. According to Ministerial Regulation No. 26 of 2010 Concerning Tariff Mechanism Formulation and Calculation of Upper Economy Class Passenger Air Transportation Services 1 Domestic Commerce, clause 1 paragraph 9-11, Airlines should provide public transportation, their types of service can be divided into three categories, namely full service, medium service and no frills service.

Public transportation (Chase 1978; 1981) generally includes the pure services and high contact. Airlines, on the other hand, can also be viewed with perspective of interaction and customization on one side and labor intensity on the other side (Schemener 1986). According to Schmenner (1986: 25), the airline transportation industry included service factory which had a low degree of interaction and customization, as well as a low degree of labor intensity. An airline's emphasis is on its service quality (Chang and Yeh 2002; Liou et al. 2011) so that it can compete with its rivals in the long run. Further, many researchers claimed that airline companies using competitive advantage in their rates cannot last for very long, compared to those companies using service quality for their customers (Chang and Yeh 2002; Jou et al. 2008).

There are two service quality paradigms, i.e.: the disconfirmation paradigm and the attitudinal paradigm (Buttle 1996). It is believed that SERVQUAL is based on the adoption of the literature of disconfirmatory customer satisfaction (Parasuraman et al. 1985). Furthermore, Parasuraman et al. (1985) showed the gap between perception and expectation in consumers, by identifying 10 components of the service quality. They continued their research during 1988, which resulted in promoting the 10 components of service quality into five dimensions, namely reliability, as surance, tangibles, empathy, and responsiveness, with a 22 item questionnaire (Parasuraman et al. 1988).

In contrast, Cronin and Taylor (1992; 1994) said that the SERVQUAL paradigm that referred to disconfirmatory satisfaction didn't succeed. They said that the quality of the services received was because of the attitude of the consumers towards the performance of the service, so it was a performance measure that should be used. Therefore, Cronin and Taylor, modified SERVQUAL to SERVPREF.

The quality of service received by consumers will affect their satisfaction, retention and positive word-of-mouth (Buttle 1996). Research from Saha and Theingi (2009) proved that the level of the quality of service provided had a direct impact on air transport passengers' satisfaction. Satisfaction is a subjective matter and can be felt after the purchase and consumption experience (Um et al. 2006). The disconfirmation paradigm can be used as a reference in evaluating or comparing the performance of the products received with the expectation ( $\mathrm{Um}$ et al. 2006). Kozak (2001b) distinguished that the satisfaction of attitude before the decision could be changed, as a result of the satisfaction. Therefore, the notion of satisfaction is that it is the end of the buying decision process (Um et al. 2006).

Moreover, the price of the fare also affects passengers when making a purchase. When air transport rates are cheaper than other modes of transportation, many passen- 
gers will switch. Indeed, in addition to Rao and Monroe (1989), it is suggested that lower fares should always be supported with good service quality.

The services marketing mix (Lovelock and Wirtz 2011: 47) stated one item that should be focused on in the airlines' service is the physical evidence or physical environment or 'servicescape.' Physical evidence is visual or other good clues that provide evidence of the service quality (Lovelock et al 2011: 622). According to Zeithaml et al. (2006), physical evidence was required in service because it could bring satisfaction to the customers. Given that, it can be argued that while service quality will affect customer satisfaction (Baker and Crompton 2000; Williams and Soutar 2009), fares and physical evidence will also do the same (Bitner 1990).

The meaning of customer satisfaction is important. Like other service industries, a satisfied passenger (or customer) is more likely to do a repurchase action (Blackwell et al. 2006). From their study, it implied that customer satisfaction can be measured by the consumers' evaluation actions after consuming products or services. The results of the evaluation lead to a repurchase action when the assessment is positive, and no repurchase action when it is negative. The repurchase action is, by far, the strong indication for a sustainable business. For example, Gupta et al. (2004) indicated that an increase of 1 percent in reuse can increase the firm's value by 5 percent. The same thing was said by Reichheld and Sasser (1990) who showed an increase of 5 percent can increase profits by between 25 percent- 85 percent.

Based on the above research, it can be argued that the problem with increased competition among airlines has spread not only into fares but also in the service quality, and the physical evidence that causes changes in satisfaction and repurchase. Thus, the issue to be discussed in this topic is how much influence do fares, service quality and physical evidence have on satisfaction and repeat buying?

\section{Literature Review}

Dodds et al. (1991) described the conceptual relationship between quality, price, and value; all of which have an influence on the willingness to purchase. Their results showed the effect of price on willingness to buy. Price can measure the degree of sacrifice needed to buy the product, and the size of the level of quality. A high price becomes the basis for a perceived high quality and causes a willingness to buy. But at the same time, a higher price indicates a higher amount of money spent, so that the sacrifice action is necessary to buy the product, and this becomes the basis for the loss of willingness to buy. Therefore, the negative effect occurs between the perceived sacrifice for the perceived value (Dodds et al. 1991).

Sweeney et al. (1996) also supported Dodds et al. (1991) and showed the negative effect of the relative price to the value and the willingness to buy. From these research works, we can claim that there is a negative effect between price and value on the willingness to buy. Price is one of the most important factors in decision making by consumers (Srivastava and Lurie 2001) and appropriate prices for consumers will have a long term impact on customer retention (Kukar and Kinney 2006).

The dimensions of service quality use 2 ways, i.e.: (1) MCDM (Multiple Criteria Decision-Making) with statistical tests and (2) VIKOR (Multicriteria Optimization and Compromise Solution). (Liou et al. 2011). 
The MCDM method is used on the basis of the existing five dimensions. The modified VIKOR method is used to solve the problem without having to use a dimension that has been used by other researchers, so that the dimensions can be taken from the problem.

The modified VIKOR method was introduced by Opricovic and Tzeng (2004). They developed the dimensions of service quality in relation to the specific problem. Research conducted by Liou et al. (2011), used a modified VIKOR about the quality of an airline's domestic services. In the aviation industry, research conducted by Nadiri et al. (2008) mentioned the quality of service in terms of five different dimensions of SERVQUAL, called AIRQUAL. Nevertheless, the AIRQUAL dimensions were derived from SERVQUAL and aimed specifically at airlines service quality.

With airlines, there are many issues which can emerge, such as passenger complaint rates because of frequently delayed departures, or the cancellation of scheduled flights, baggage issues, and poor customer relations (Taylor 2001). In general, the quality of aviation services is driven by 10 main factors, namely timeliness, check-in, flight schedules, seat comfort, the location of the entrance, the interior of the aircraft, flight attendants, service after the flight, food service and pilots' on-duty hours (Glab 1998). Consumer complaints about flights included complaints about the purchase of tickets, ticket refunds, rates, customer services, advertising and other problems, and also about timing issues, problems with boarding, and baggage handling. (Rhoades and Waguespack 2008). Consumers also expressed anger about problems with flights, flight delays and cancellations, differing models for pricing, flight restrictions, and airline/airport employees.
The airlines are a service industry, so they should provide a good quality of service to their consumers (Rhoades et al. 2008). ISO 14001 emphasized improving customer satisfaction, the airlines' image and reputations, and increased domestic market share (Korul 2005: 54). Interpersonal relationships are a key factor to reduce consumer dissatisfaction but are very often associated with the place or environment where the service was provided. The place is instrumental in delivering an image of good quality service. This concept is called 'servicescape' (Edvardsson and Strandvik 2000: 89). Some studies by $\mathrm{Hu}$ and Burning (1978); Rietchie et al. (1980); and Abraham (1983), split flight services into four stages as follows.

1. Pre-journey, this is the process of the service provided to passengers prior to their flight. This includes information schedules, flight routes, reservations and booking the ticket.

2. Pre-flight services to passengers who are going to fly. At this stage, the activities at the airport include: The check-in process, checked baggage handling, waiting room/ lounge facilities, and the boarding process. The airlines are highly dependent on the existing facilities and infrastructure at the airport.

3. In-flight or onboard is the service provided to passengers during the flight. The services include seat width and leg room, cabin and seat cleaning, food and beverage service, information and reading services, toilets, and general cabin crew service.

4. Post-flight services are those provided to the passengers after their flight is completed. These services include baggage retrieval, connecting flight information, lost baggage handling, and management complains. 
This research offers a continuation of the work by Liu et al. (2011), by establishing the quality of services applying the 4 stages listed above of pre-journey, pre-flight, inflight and post-flight. This study also incorporated the indicators used by Liou et al. (2011) in developing the questionnaires.

Bitner (1992), introduced a model of environmental psychology and developed a comprehensive model, named 'servicescape.' Bitner found out that a psychological environment may have impact on customers. They can feel happy or sad towards the service environment. Happy customers can lead to an action to purchase or repurchase the offered service while the unhappy one will likely cancel the purchase or repurchase action. Hence, Bitner developed further relation between service and scape, merged into "serviscape" or also known as physical evidence.

'Servicescape,' as proposed by Bitner in 1992 is still a good reference. Lovelock; et.al. (2011) and Zeithaml et al (2009) used it when explaining the service environment or the physical evidence. Physical appearance affects consumers by improving their satisfaction (Bitner 1992). The physical appear- ance of the airline must be considered, because its effect on satisfaction will lead to customer retention.

Therefore, it can be argued that physical appearance can be treated separately from the concept of service quality itself since its presence is dominant. The presence of physical appearance can also negate the meaning of tangible. This study proposes to separate the physical appearance aspect from service quality, and find its significance throughout the overall model. It is suggested that the presence of physical evidence can stand alone, and affect satisfaction without being associated with quality. This will be a contribution by this research to its predecessors.

A satisfied customer is more likely to use that particular airline again (Oliver 1999; Stewart 1997; and Reichheld 1996). The satisfied consumer will come back and spend more money due to the level of satisfaction experienced from previous purchases (Jones and Sasser 1995; Higgins 1997; and Lewis 1998). According to Yi and La (2004), Yi (1990), satisfaction can be measured by the number of complaints, return business and positive word-of-mouth referrals. When satisfaction is created, the customer will buy the

\section{Figure 1. The Research Model}

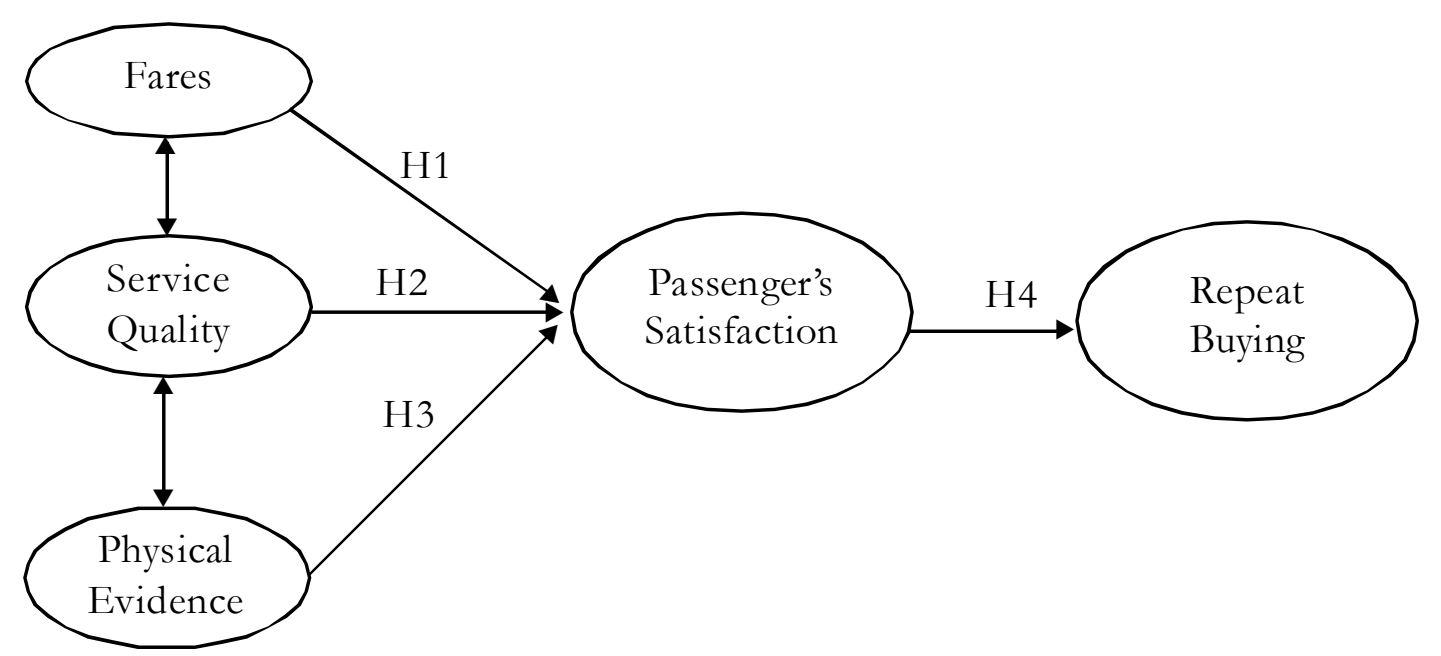


product or service again. Therefore, we can use repeat buying as a measure of satisfaction.

Given all the discussions above, this research proposes the research model as Figure 1.

\section{Hypotheses}

$H_{1}$ : There is an influence by fares on passengers' satisfaction.

Passengers' satisfaction can occur when the fare that is charged matches the benefits received, and if they are not appropriate, then that can cause dissatisfaction (Lapre and Tsikriktis 2006, received value for fares cause satisfaction Grace 2005).

$H_{2}$ : There is an influence by service quality on passengers' satisfaction

Service quality, if carried out well, will give rise to satisfaction. With increasing competition among the airlines, service quality becomes important for the strategic planning/management of a company (Chang and Yeh 2002; and Buttle 1994).

$H_{3}$ : There is an influence from the physical evidence on passengers' satisfaction.

The physical evidence comprises the ways in which customers can be attracted to and/or satisfied by a firm's services (Bitner 1992; Ryu et al. 2012). The influence of these tangibles and intangibles upon service quality is a widely debated issue by the marketing literature, despite the apparent lack of consensus on the relative importance of every dimension (Pantouvakis and Lymperopoulos 2008). Therefore, in the service marketing mix, we propose physical evidence as a measurement to declare the presence of tangibles in services (Lovelock et al. 2009).
$H_{4}$. There is an influence from passengers' satisfaction on repeat buying

Passenger's satisfaction causes repeat buying (Chen 2008). Consumer satisfaction is an antecedent which causes the repeat buying (Bukhari et al. 2013).

\section{Methodology}

Sampling was done using cluster random sampling. The potential samples were passengers present at Soekarno-Hatta airport. The number of samples totaled 317 passengers, arrived at using random counting. This research performed reliability and validity tests for all the variables used in this study. The reliability test results, listed in Table 1 , showed that all of the variables studied were reliable with a value above 0.7 . The reliability's measurement scale should have a

Table 1. Result of Reliability

\begin{tabular}{lll} 
No. & $\begin{array}{c}\text { Sub Variable/ } \\
\text { Variable }\end{array}$ & $\begin{array}{c}\text { Cronbach's } \\
\text { Alpha }\end{array}$ \\
\hline 1 & Fares & 0.797 \\
2 & Information & 0.835 \\
3 & Ticket & 0.880 \\
4 & Check-in & 0.832 \\
5 & On time & 0.860 \\
6 & In-flight & 0.824 \\
7 & Post-flight & 0.896 \\
8 & External & 0.817 \\
9 & Internal & 0.885 \\
10 & Satisfaction & 0.925 \\
11 & Repeat & 0.770 \\
\hline
\end{tabular}


Gadjah Mada International Journal of Business - September-December, Vol. 17, No.3, 2015

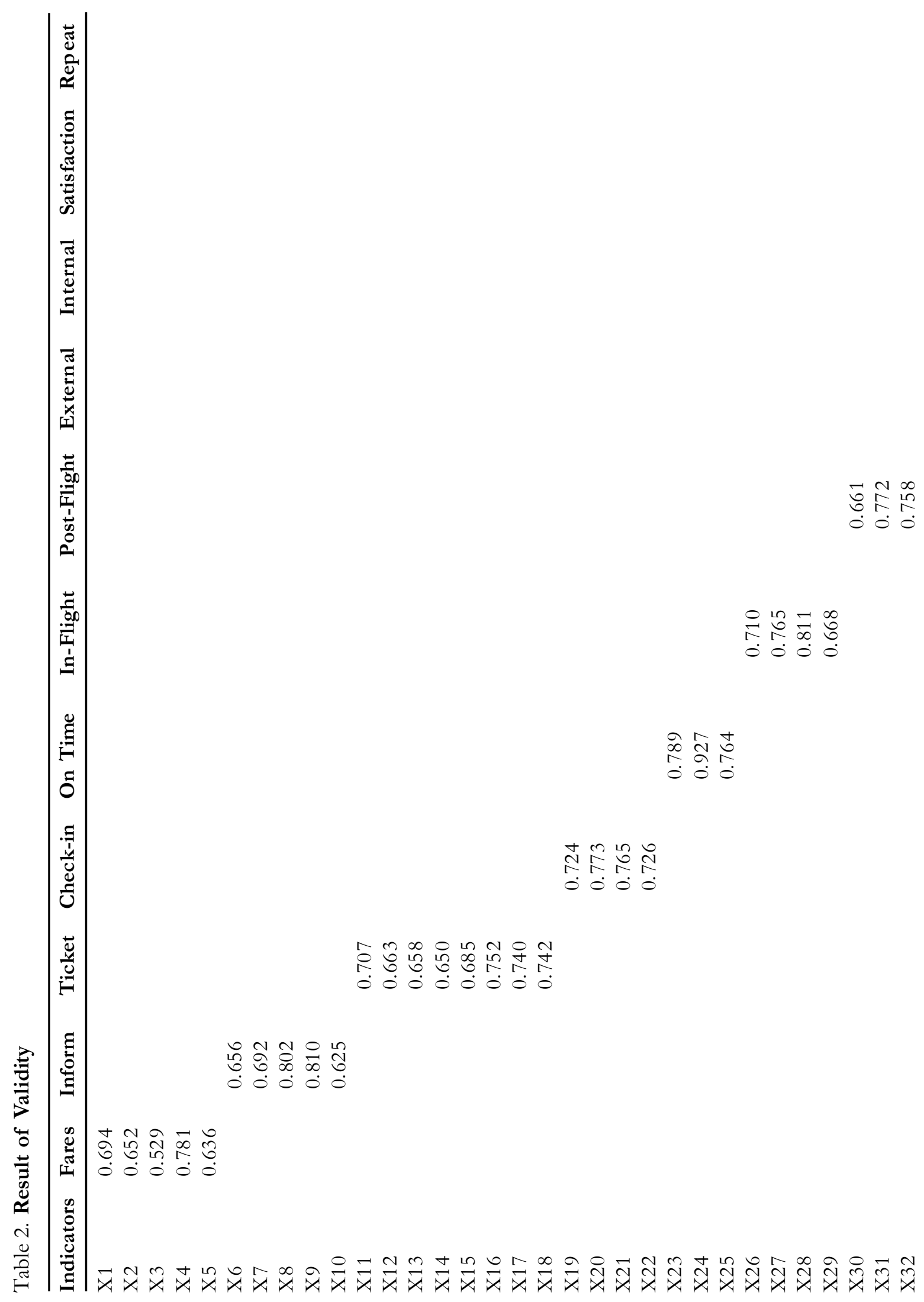


Soelasih

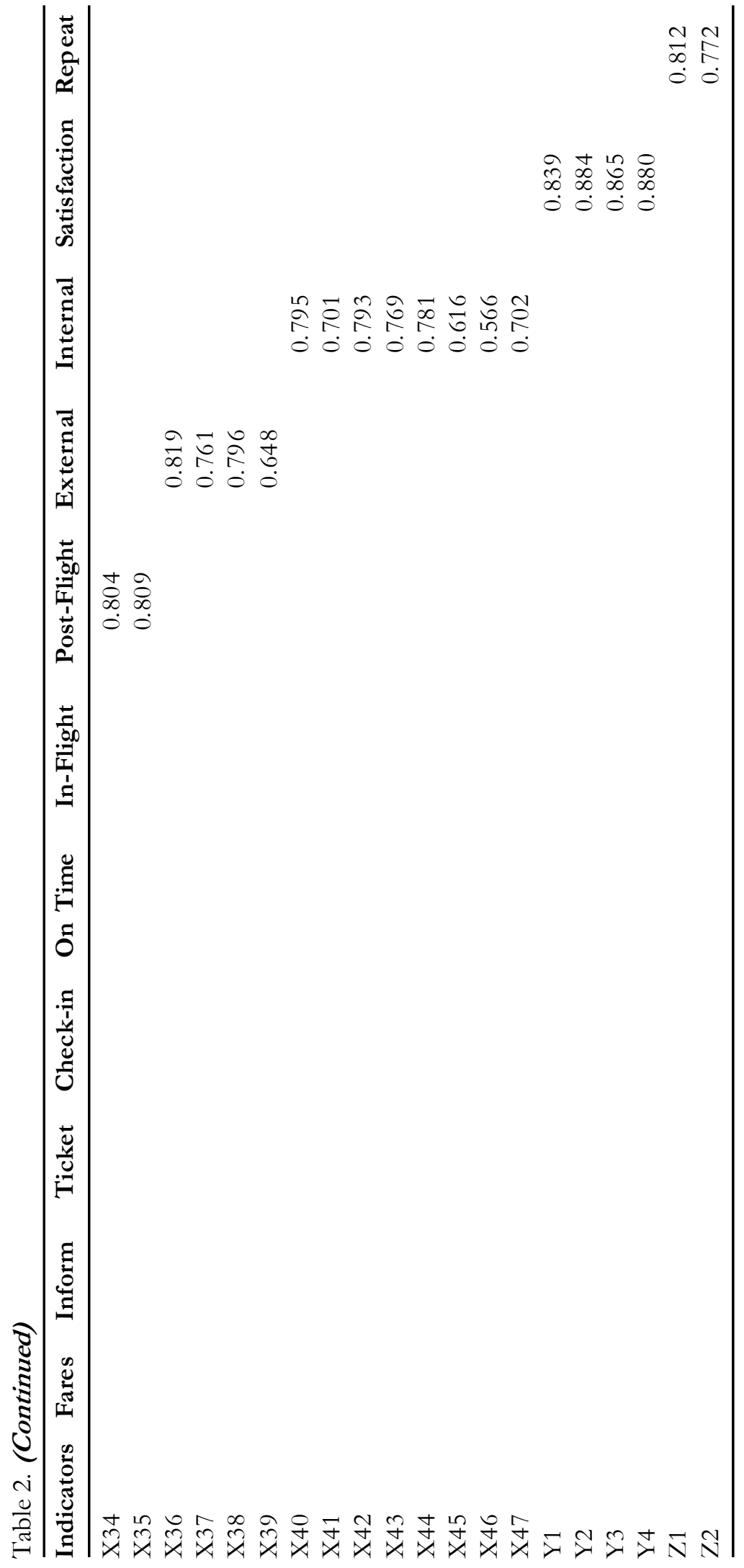


Cronbach Alpha value of at least 0.70 (Nunnally 1978; Nunnaly and Bernstein 1994).

Test validity using confirmatory factor analysis, and validity of test results, presented in Table 2. The validity of the test results showed that all indicators can shape the dimensions and variables studied, with a value above 0.5 . The reliability and validity of the test results showed that all of the variables were eligible for use in this study.

After testing the validity and reliability, we then tested the model using a Structural Equation Model.
Test results of the suitability models based on chi-square/degrees of freedom, RMSEA, SRMR, NFI, NNFI, and CFI, as shown above, produced an acceptable model, although the assessments that were based on chi-square, $p$ value, GFI and AGFI generated suitability test of the model were only a marginal fit. However, $\mathrm{Hu}$ and Bentler (1998) recommended the use of SRMR, supplemented by NNFI, CFI, or RMSEA derived from ML and GLS estimations for goodness of fit. This research used the Maximum Likelihood (ML) method for the SEM. Overall, the model test results of the model explained the relationship between the variables

Table 3. Test Results Suitability Model (GOF)

\begin{tabular}{lccc}
\hline Fit Measure & Good Fit & Acceptable Fit & Estimated \\
\hline $\mathrm{X}^{2}$ (Chi-square) & $0 \leq \mathrm{X}^{2} \leq 2 \mathrm{df}$ & $2 \mathrm{df} \leq \mathrm{X}^{2} \leq 3 \mathrm{df}$ & $\mathrm{X}^{2}=2903.36$ \\
$\mathrm{p}$ value & $0.05<\mathrm{p}<1.00$ & $0.01 \leq \mathrm{p} 0.05$ & $\mathrm{p}$-value $=0.00$ \\
$\mathrm{X}^{2} / \mathrm{df}$ & $0 \leq \mathrm{X}^{2} / \mathrm{df} \leq 2$ & $2<\mathrm{X}^{2} / \mathrm{df} \leq 3$ & 2.22 \\
RMSEA & $0 \leq \mathrm{RMSEA} \leq 0.05$ & $0.05 \leq \mathrm{RMSEA} \leq 0.08$ & 0.07 \\
P value for test of & & & \\
close fit & & $0.05<\mathrm{p} \leq 1.00$ & 0.00 \\
RMSEA $<0,05)$ & $0.10<\mathrm{p} \leq 1.00$ & & \\
Confidence interval & $0 \leq \mathrm{SRMR} \leq 0.05$ & $0.05 \leq \mathrm{SRMR} \leq 0.10$ & 0.07 \\
NFI & $0.95 \leq \mathrm{NFI} \leq 1.00$ & $0.90 \leq \mathrm{NFI} \leq 0.95$ & 0.96 \\
NNFI & $0.97 \leq \mathrm{NNFI} \leq 1.00$ & $0.95 \leq \mathrm{NNFI} \leq 0.97$ & 0.98 \\
CFI & $0.97 \leq \mathrm{NNFI} \leq 1.00$ & $0.95 \leq \mathrm{NNFI} \leq 0.97$ & 0.98 \\
GFI & $0.95 \leq \mathrm{NNFI} \leq 1.00$ & $0.90 \leq \mathrm{NNFI} \leq 0.95$ & 0.73 \\
AGFI & $0.90 \leq \mathrm{AGFI} \leq 1.00$ & $0.85 \leq \mathrm{AGFI} \leq 0.90$ & 0.70 \\
& close to GFI & close to GFI & \\
\hline
\end{tabular}

Source: Engel et al. (2003)

Models: Tests of Significance and Descriptive Goodness-of-Fit Measures and estimated 
of fares, service quality, physical evidence, passengers' satisfaction and the repeat buying of domestic commercial flights with low cost carriers in Indonesia.

\section{Analysis and Result}

\section{Passengers' Characteristics}

Table 4 shows that most passengers had a bachelors degree (S1), most worked as private company employees, and the majority were between the ages of 21-30 years old. The data showed that the passengers were people who were highly mobile, so they de-

Table 4. Passengers Characteristics

\begin{tabular}{|c|c|c|}
\hline Information & Amount & Persentase $(\%)$ \\
\hline \multicolumn{3}{|l|}{ Gender: } \\
\hline Male & 237 & 74.8 \\
\hline Female & 80 & 25.2 \\
\hline \multicolumn{3}{|l|}{ Age: } \\
\hline$<20$ years & 18 & 5.7 \\
\hline $21-30$ years & 110 & 34.7 \\
\hline $31-40$ years & 88 & 27.7 \\
\hline $41-50$ years & 67 & 21.1 \\
\hline $51-60$ years & 29 & 9.1 \\
\hline$>60$ years & 5 & 1.7 \\
\hline \multicolumn{3}{|l|}{ Educations: } \\
\hline High school & 90 & 28.4 \\
\hline Diploma & 39 & 12.3 \\
\hline Undergraduate & 138 & 43.5 \\
\hline Graduate & 38 & 12.0 \\
\hline Doctoral Degree & 1. & 0.4 \\
\hline Others & & \\
\hline \multicolumn{3}{|l|}{ Jobs: } \\
\hline Student & 18 & 5.7 \\
\hline Entrepreneur & 54 & 17.0 \\
\hline Governmentemployees & 105 & 33.1 \\
\hline Private employees & 112 & 35.3 \\
\hline Others & 28 & 8.9 \\
\hline
\end{tabular}

sire and expect on-time travel performance when using air transportation.

\section{Overal Structural Model and Hypothesis Testing}

The results of the data processing to answer the hypotheses under study using SEM with Lisrel program are as Table 5.

The results of testing Hypotheses 1, 2, and 4 individually showed the $H_{0}$ was rejected, so that $H_{1}$ was accepted, which means that for each test between fares and service quality, they both influenced the passengers' satisfaction. Passengers' satisfaction also had an influence on repeat buying. Meanwhile, hypothesis 3 for $H_{1}$ was rejected, as physical evidence had no effect on the passengers' satisfaction.

However, from the overall equation result as Equation 1, the physical evidence was not significant. It means that the physical evidence did not have any impact on passengers' satisfaction.

$$
\begin{aligned}
& \text { satisfac }=0.347 * \text { fares }+0.403 * \text { servqual } \\
& (0.0794) \quad(0.135) \\
& 4.365 \quad 2.985 \\
& +0.125 * \text { physical, Errorvar. }= \\
& \text { (0.134) } \\
& 0.931 \\
& 0.333, \mathrm{R}^{2}=0.667 \\
& (0.0429) \\
& 7.775
\end{aligned}
$$

The equation shows that the physical evidence does not have any impact on passengers' satisfaction, as shown by the value of $t$ being below 1.96. It meant that the important variables in shaping passengers' sat- 
Table 5. Hypotheses Testing Fares, Service Quality, and Physical Evidence of Passenger Satisfaction

\begin{tabular}{|c|c|c|c|c|c|c|}
\hline No. & Hypothesis & $\begin{array}{c}\text { Path } \\
\text { Coefficient }\end{array}$ & t-value & t-table & Result & Conclusion \\
\hline 1. & $\begin{array}{l}\text { The effect fares } \\
\text { toward passenger's } \\
\text { satisfaction }\end{array}$ & 0.347 & 4.365 & 1.96 & significant & $\begin{array}{l}\mathrm{H}_{0} \text { is rejected, there } \\
\text { is influence between } \\
\text { fares to passenger's } \\
\text { satisfaction }\end{array}$ \\
\hline 2. & $\begin{array}{l}\text { The effect service } \\
\text { quality toward } \\
\text { passenger's } \\
\text { satisfaction }\end{array}$ & 0.403 & 2.985 & 1.96 & significant & $\begin{array}{l}\mathrm{H}_{0} \text { is rejected, there } \\
\text { is influence between } \\
\text { service quality to } \\
\text { passenger's } \\
\text { satisfaction }\end{array}$ \\
\hline 3. & $\begin{array}{l}\text { The effect physical } \\
\text { evidence toward } \\
\text { passenger's } \\
\text { satisfaction }\end{array}$ & 0.125 & 0.931 & 1.96 & $\begin{array}{c}\text { no } \\
\text { significant }\end{array}$ & $\begin{array}{l}\mathrm{H}_{0} \text { is accepted, there } \\
\text { is no influence } \\
\text { between physical } \\
\text { evidence to } \\
\text { passenger's } \\
\text { satisfaction }\end{array}$ \\
\hline 4 & $\begin{array}{l}\text { The effect passenger's } \\
\text { satisfaction toward } \\
\text { repeat buying }\end{array}$ & 0.843 & 13.708 & 1.96 & significant & $\begin{array}{l}\mathrm{H}_{0} \text { is rejected, there } \\
\text { is influence between } \\
\text { passenger's } \\
\text { satisfaction to } \\
\text { repeat buying }\end{array}$ \\
\hline
\end{tabular}

isfaction with low cost carrier airlines in Indonesia were their fares and service quality.

The overall results from LISREL are shown at Figure 4. Passengers still consider that the physical evidence is a part of the service quality, which was why the difference between the physical evidence and service quality was not visible during testing. Arguably, the difference will be visible when there is a clear distinction between the service quality and physical evidence. Parasuraman (1985) stated that service quality had five dimensions, namely tangible, reliability, responsiveness, empathy and assurance. Tangible overlaps with physical evidence. Bitner
(1992) proposed the theory, which was later established by Lovelock et al. (2011) and Zeithaml et al. (2009), in which they stated the variable 'servicescape' or physical evidence, was one of the variables in the service marketing mix besides service quality.

In relation to these theories, this study attempted to split the service that is part of service quality, with the six dimensions of information, ticketing, check-in, on-time performance, in-flight and post-flight, while the tangible physical evidence variable was used with two external and internal dimensions. Hence, the emphasis on service quality was something that was assessed on the intan- 
gible, while the physical evidence was on the tangible. The results of the research showed that something which was felt by passengers raised their level of satisfaction higher than something that could be seen by them. This was what caused physical evidence to have no influence on passengers' satisfaction.

\section{Figure 4. Output Lisrel}

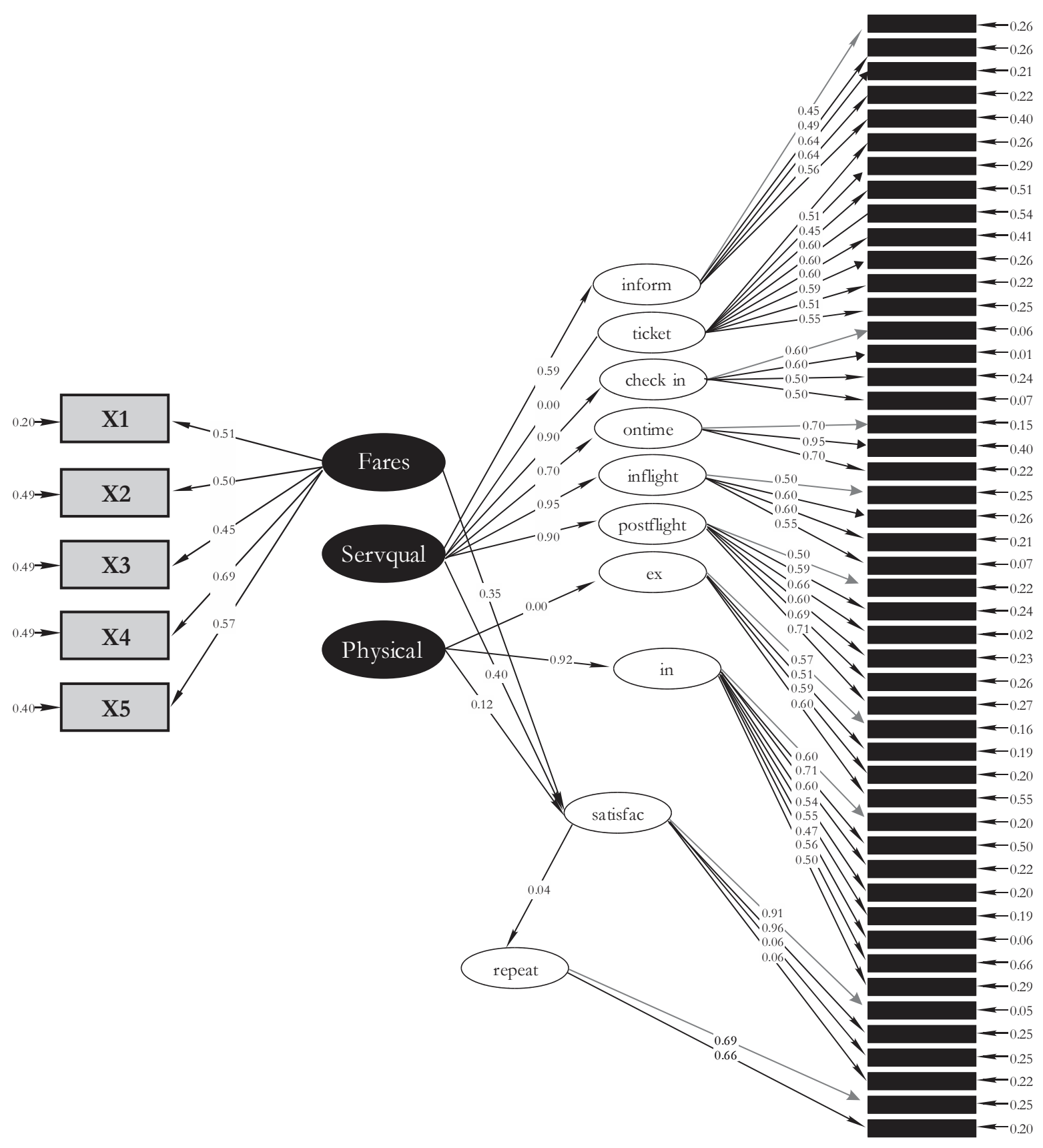




\section{Conclusion}

This study confirmed that the fares passengers have to pay had a positive influence on their satisfaction, which was different from the study of Dodds et al. (1991) and Sweeney et al. (1996). Their results showed that the relative price had a negative effect on the perceived value.

This study also showed that the discussion on service quality dimensions can be formed out of the proposed problems. The result indicated that there were six dimensions that consist of information, ticketing, check-in, on-time performance, in-flight and post-flight. Hence, these findings also supported the research work by Liou (2011).

Lastly, this study has taken some effort to separate tangible in the service quality from the physical evidence, so that the service quality dimensions studied were intangible. This differs from the work of previous studies on this topic. However, the results of this study indicated that the physical evidence did not have any impact on passengers' satisfaction, which implied that the tangible dimension cannot be eliminated from the service quality.

To answer this issue, we propose further research into the effort to distinguish the difference between service quality and physical evidence. It will make a contribution to supporting the theory expressed by Lovelock (2011) that the service needed some additions to the marketing mix, to be called the service marketing mix, one of which was physical evidence; and it also supports the theory of the 'servicescape' by Bitner (1992).

\section{References}

Abraham, M. 1983. A service quality model in air travel demand: An empirical study. Transportation Research 17A (5): 385-393.

Baker, D. A. and J. L. Crompton. 2000. Quality, satisfaction and behavioral intentions. Annals of Tourism Research 27 (3): 785-804.

Bitner, M. J. 1990. Evaluating service encounters: The effects of physical surroundings and employee responses. Journal of Marketing 54 (April): 69-82.

Bitner, M. J. 1992. 'Servicescape': The impact of physical surroundings on customers and employees. Journal of Marketing 56 (April): 57-71.

Blackwell, R., C. D’Souza, M. Taghian, P. Miniard, and J. Engel. 2006. Consumer Behaviour: An Asia Pacific Approach. Thomson: 171.

Bukhari, S. M. F., A. Ghoneim, C. Dennis, and B. Jamjoon. 2013. The antecedents of travellers' e-satisfaction and intention to buy airline tickets online, a conceptual model. Journal of Enterprise Information Management 26 (6): 624-641.

Buttle, F. 1996. SERVQUAL: review, critique, research agenda. European Journal of Marketing 30 (1): 8-32.

Chang, Y-H., and C-H. Yeh. 2002. A survey analysis of service quality for domestic airlines. European Journal of Operational Research 139, 166-177.

Chase, R. B. 1978. Where does the customer fit in a service operation? Harvard Business Review 56 (6) (November-December): 137-142. 
Chase, R. B. 1981. The customer contact approach to services: Theoretical bases and practical extension. Operations Research 29 (4): 698-706.

Chen, C-F. 2008. Investigating structural relationships between service quality, perceived value, satisfaction, and behavioral intentions for air passengers: Evidence from Taiwan. Transportation Research (Part A 42): 709-717.

Cronin Jr., J. J. S. A. Taylor. 1994. SERVPERF Versus SERVQUAL: Reconciling performance - based and perceptions - minus - expectations measurement of service quality. Journal of Marketing 58 (January): 125-131.

Cronin Jr. J. J., and S. A. Taylor. 1992. Measuring service quality: A reexamination and extension. Journal of Marketing 56 (3) (July): 55-68.

Dodds, W. B.; K. B. Monroe, and D. Grewal. 1991. Effects of price, brand, and store information on buyers' product evaluations. Journal of Marketing Research (Aug 28) (3). ABI/INFORM Global.

Edvardsson, B., and T. Strandvik. 2000. Is a critical incident critical for a customer's relationship? Managing Service Quality 10 (2): 82-91.

Engel, K. S., H. Moosbrugger, and H. Muller. 2003. Evaluating the fit of structural equation models: Tests of significance and descriptive goodness-of-fit measures. Methods of Psychological Research Online 8 (2): 23-74.

Glab, J. 1998. The people's choice. Frequent Flyer (June): 24-8.

Grace, D. 2005. Consumer disposition toward satisfaction (CDS): Scale development and validation. Journal of Marketing Theory and Practice 13 (2) (Spring): 20-31.

Gupta S., D. R. Lehmann, and A. Stuart. 2004. Valuing customers. J Mark Res 2004;41(1):7-18.

Higgins, K.T. 1997. Coming of Age: Despite Growing Pains, Customer Satisfaction Measurement Continues to Evolve. Marketing News, 1-12.

Hu, L., and P. M. Bentler. 1998. Fit indices in covariance structure analysis: Sensitivity to under parameterized model misspecification. Psychological Methods (3): 424-453.

Hu, M. and E. T. Burning. 1978. A comparison of Enduring and Instrumental product/service importance: The case of the airline traveler. Transportation Practitioners Journal 54: 31-40.

Korul, V. 2005. Guide to the implementation of ISO 14001 at airports. Journal of Air Transportation 10 (2): 49-68.

Kozak, M. 2001b. A critical review of approaches to measure satisfaction with tourist destinations. In J. A. Mazanec, G. I. Crouch, J. R. B. Ritchie, A. G. Woodside (Edts.), Consumer Psychology of Tourism Hospitality and Leisure 2. New York: CABI Publishing.

Kukar-K. M. 2006. The role of price-matching characteristics in influencing store loyalty. Journal of Business Research 59 (4):475-482.

Lapre, M. A., and N. Trikriktsis. 2006. Organizational learning curves for customer dissatisfaction: Heterogeneity across airlines. Management Science 52 (3) (March): 352-366.

Lewis, S. 1998. All or nothing: Customer must be "Totally Satisfied." Marketing News: 11-12.

Liou, J. J. H., C-Y. Tsai, R-H. Lin, and G-H. Tzeng. 2011. A modified VIKOR multiple-criteria decision method for improving domestic airlines service quality. Journal of Air Transport Management 17: 5761. 
Lovelock, C., and J. Wirtz. 2011. Services Marketing People, Technology, Strategy. (7 $7^{\text {th }}$ ed.). Pearson International Edition: 27-37, 160. 277, 280-283

Jones, T. O. and W. E. Sasser Jr. 1995. Why satisfied customers defect. Harvard Business Review (Nov.-Dec.).

Jou, R-C., S-H. Lam, D. Hensher, C-C. Chen, and C-W. Kuo. 2008. The effect of service quality and price on international airline competition. Transportation Research (part E): 580-592.

Mangold, G. W., and E. Babakus. 1991. Service quality: The front-stage perspective vs the back stage perspective. Journal of Services Marketing 5 (4) (Autumn): 59-70.

Nadiri, H., K. Hussain, E. H. Ekiz, and S. Erdogan. 2008. An investigation on the factors influencing passengers' loyalty in the North Cyprus national airline. The TQM Journal 20 (3): 265-280.

Nunnally J. C. 1978. Psychometric Theory (2 ${ }^{\text {nd }}$ ed.). New York: McGraw Hill.

Nunnally J. C., and I. H. Bernstein. 1994. Psychometric Theory (3 ${ }^{\text {rd }}$ ed.). New York: Mc Graw Hill.

Oliver, R. L. 1999. Whence consumer loyalty? Journal of Marketing 63: 33-34.

Pantouvakis, A., and K. Lymperopoulos. 2008. Customer satisfaction and loyalty in the eyes of new and repeat customers: Evidence from the transport sector. Managing Service Quality 18 (6): 623-643.

Parasuraman, A., V. A. Zithaml, and L. L. Berry. 1985. A Conceptual model of Service Quality and Its Implications for Future Research. Journal of Marketing 49 (Fall): 41-50.

Parasuraman, A., V. A. Zithaml, and L. L. Berry. 1988. SERVQUAL: A multiple-item scale for measuring consumer perceptions of service quality. Journal of Retailing 64 (1).

Rao, A. R., and K. B. Monroe. 1989. The effect of price, brand name, and store name on buyers' perceptions of product quality: An integrative review. Journal of Marketing Research XXVI (August): $351-7$.

Reichheld, F. F. 1996. Learning from customer defections. Harvard Business Review 59.

Reichheld, F., and W. Z. Sasser. 1990. Zero defections: Quality comes to services. Harvard Business Review 68 (5): 105-11.

Rhoades, D. L., and B. Waguespack Jr. 2008. Twenty years of service quality performance in the US airline industry. Managing Service Quality 18 (1): 20-33.

Richard, M. D. and A. W. Allaway. 1993. Service quality attributes and choice behavior. Journal of Service Marketing 7 (1): 59-68.

Ritchie, J. R., E. E. Johnston, and V. J. Jone. 1980. Competition, fares and fence-perspective of the air traveler. Journal of Travel Research 27: 36-42.

Ryu, K., H-R. Lee, and W. G. Kim. 2012. The influence of the quality of the physical environment, food, and service on restaurant image, customer perceived value, customer satisfaction, and behavioral intentions. International Journal of Contemporary Hospitality Management 24 (2): 200-223.

Saha, G. C., and Theingi. 2009. Service quality, satisfaction, and behavioral intentions: A study of low-cost airline carriers in Thailand. Managing Service Quality 19 (3): 350-372.

Schmenner, R. W. 1986. How can service businesses survive and prosper? Sloan Management Review 27 (3) (Spring): 21-32 (http://www.researchgate.net/publication/12997398_How_Can_Service_ Business_Survive_and_Prosper)

Srivastava, J; and N. Lurie. 2001. A consumer perspective on price-matching refund policies: Effect on price perceptions and search behavior. Journal of Consumer Research 28 (2): 296-307. 
Stewart, T. A. 1997. A satisfied customer is not enough. Fortune: 112-113.

Sweeney, J. C., G. N. Soutar, and L. W. Johnson. 1996. Retail service quality and perceived value. Journal of Retailing and Consumer Services 4 (1): 39-48.

Taylor, L. R. 2001. Miles to go, promises to keep. Government Excutive 33 (4): 81-84.

Um, S., K. Chon, and Y. H. Ro. 2006. Antecedents of revisit intention. Annals of Tourism Research 33 (4): $1141-1138$.

Williams, P., and G. N. Soutar. 2009. Value, Satisfaction and Behavioral Intentions in an Adventure Tourism Context. Annals of Tourism Research 3: 413-438.

Yi, Y. 1990. A critical review of consumer satisfaction. Review of Marketing: 68-123.

Yi, Y., and S. La. 2004. What influences the relationship between customer satisfaction and repurchase intention? Investigating the effects of adjusted expectations and customer loyalty. Psychology and Marketing 21 (5): 351-373.

Zeithaml, V. A., M. J. Bitner, and D. D. Gremler. 2006. Services Marketing: Integrating Customer Focus Across Firms ( ${ }^{\text {th }}$ ed.) McGraw-Hill International Edition: pp. 4, 5, 22, 26-28, 521-527, 320-321

Zeithaml, V. A., M. J. Bitner, and D. D. Gremler. 2009. Services Marketing: Integrating Customer Focus Across Firms (5 ${ }^{\text {th }}$ ed.) McGraw-Hill International Edition. pp: 4, 5, 20, 23-25, 313-321, 353, 519-525. 
